\title{
Analysis of the distribution of World Bank disbursements in Latin America between 1985 and 2010
}

Análise sobre a distribuição de desembolsos do Banco Mundial na América Latina entre 1985 e 2010

\author{
Renato Câmara Nunes Dias \\ Universidade de São Paulo \\ Carlos César Santejo Saiani \\ Universidade Federal de Uberlândia \\ Carlos Eduardo Carvalho \\ Pontifícia Universidade de São Paulo
}

Ana Lúcia Pinto da Silva

Universidade Presbiteriana Mackenzie

\section{Abstract}

This article analyzes the distribution of World Bank disbursements in Latin America and the Caribbean, in the period between 1985 and 2010, among countries and economic sectors. Its objective is to identify tendencies that help understand the criteria that guide WB activities and how these criteria relate to WB's understanding on its declared mission of combating extreme poverty. The article tests the existence of such criteria, with the econometric analysis of disbursements per country in relation to per capita income, poverty, GINI index, population, political regimes, investment, and government expenditure. Disbursements distribution among economic sectors is also analysed in selected timespans. In order to analyse the results, the article uses the criterion of "adherence" among the priorities in resources distribution, countries' indicators and the nature of privileged sectors. The analysis on resources distribution may also contribute to the understanding of how the WB understands the meaning of the guidelines it states.

\section{Keywords}

distribution of World Bank disbursements; Latin America and the Caribbean; poverty; extreme poverty; international aid

JEL Codes F35; F53; I30.

\section{Resumo}

$O$ artigo analisa a distribuição dos desembolsos do Banco Mundial (BM) na América Latina e Caribe, de 1985 a 2010, entre países e entre setores econômicos. O objetivo é identificar tendências que ajudem a compreender os critérios que orientam a atuação do $B M$ e como esses critérios se articulam com o entendimento do BM sobre sua missão declarada de combater a pobreza extrema. $O$ artigo testa a existenncia desses critérios, pela análise econométrica dos desembolsos por país em relação a renda per capita, pobreza, indice de Gini, população, regime político, investimento, gastos do governo. Analisa-se também a distribuição dos recursos por setores da economia, em subperíodos selecionados. Para a análise dos resultados, adota-se o critério de "aderência" entre as prioridades na divisão dos recursos, os indicadores dos países e a natureza dos setores privilegiados. A análise da divisão dos recursos pode contribuir também para a compreensão de como o próprio $B M$ entende os significados das orientações que afirma seguir.

\section{Palavras-chave}

distribuição de desembolsos do Banco Mundial; América Latina e Caribe; pobreza; pobreza extrema; ajuda internacional

Códigos JEL F35; F53; I30. 


\section{Introduction}

This paper analyzes the actions of the World Bank (WB) in Latin America and the Caribbean (LAC) based on a recipients-oriented perspective: an analysis which aims at trying and identifying trends in the Bank's resources distribution in relation to a set of economic and social indicators, among economic sectors, that outline LAC countries reality as recipients.

While studying the actions of international financial institutions, such as the WB, three main perspectives are commonly used as analytical guidelines. While many authors focus on the efficiency of WB's projects in specific countries and regions (Hansen; Tarp, 2000; Nath, 2005; Santiso, 2001; Ismi, 2004; Bourguingnon; Sundberg, 2005), in a literature one might name as aid effectiveness literature; others look into the WB through the lenses of what one may call governance literature, trying and understand the Bank's institutional arrangements and issues (Vikas, 2001; Griffith-Jones, 2002; Buira, 2005; Bhalla, 2006; Foch, 2007; Kaluza; Kaluza, 2008). Moreover, others center their analytical efforts on what one may name conceptions literature, one that revolves around the Bank's discourse and its alleged purposes and stated objectives, made more or less clear in its official documents and World Development Reports (Hibou, 2000; Teixeira, 2009; Pereira, 2010; Vianna Jr., 2008; Rached, 2010).

The authors of the present work, however, believe there is much to be studied on what seems to motivate the WB to distribute its resources. Hence, recognizing the importance of the conceptions literature, instead of analysing the criteria enshrined in WB official documents, we aim at identifying criteria actual trends by analysing the true disbursements distribution made by the bank in Latin America and the Caribbean.

Thus, moving away from most of the analyses on the WB, we look for the criteria that seem to guide disbursements: although not the declared reasons, those that may be identified with a close and thorough look at ( $i)$ the countries' socio-economic profiles, outlined by indicators such as gross domestic product (GDP), per capita GDP, poverty, Gini Index, institutional indexes, etc., (ii) the economic sectors prioritized by the financial flows disbursed by the WB. While most analysts look into the Bank itself, our perspective is quite another: to look at the group of countries that receive the Bank's resources, to try and understand which of their characteristics 
establish a safe ground to assess, based on the WB's alleged preoccupation with poverty, the organization's actions.

This paper's objectives can be defined as follows:

(i) quantify disbursements distribution among countries in Latin America and the Caribbean, with data offered by the World Bank's projects database;

(ii) to analyze if there are clear criteria that may explain the distribution of resources among countries in the region, using econometric tests that relate existing resources distribution with countries' characteristics. These features have been selected by the authors because of their relation to the World Bank's stated mission of "fighting extreme poverty": countries' per capita income, poverty levels, inequality (Gini index), GDP, democracy, investment levels, government expenditure. The authors seek to identify, based on the resources distribution analysis, how the World Bank renders its mission of fighting real poverty - that is, if some tested characteristics better explain the amounts received by LAC countries;

(iii) to analyze resources distribution among economic sectors for the set of countries in the region, with the same purpose of identifying sectorial preferences by the $\mathrm{WB}$ and the relation of these preferences with the Bank's alleged mission of fighting extreme poverty.

(iv) to establish the relation, once the quantitative analysis on resources distribution among countries and sectors is made, between the results and WB's discourse on how poverty should be tackled, based on the Bank's own documents and selected works on its comprehension on fighting poverty.

The analysis on resources distribution among economic sectors, in the set of countries, is done using the classification made by the World Bank, which sorts its projects in "Major Sectors". The tagging - made by the Bank in its projects database - of every project with up to 5 of the 10 Major Sectors may account for arbitrariness, which may affect the results quality. However, it is impossible to scrutinize every project in detail. The data has been sorted into five sub-periods, so that the WB preferences changes can be more easily identified, thus offering meaningful conclusions on how the Bank operates its mission of fighting extreme poverty.

As the analysis looks for trends in disbursements in relation to LAC countries' socio-economic profiling, a new concept is proposed: adherence, which can be understood as the approximation between ( $i$ ) the bank's 
action (resources disbursement distribution) and (ii) the recipients' socio-economic needs. In other words, adherence may be identified when higher disbursements amounts are offered to countries with relative lower economic and social standards. Hence, this paper will test the hypothesis that lower economic and social standards in countries are met with relative larger amounts of disbursements by the bank, which would indicate adherence. Any other scenario would indicate a lack of adherence, which, in its turn, would lead to the conclusion that there is a certain lag between the WB's discourse and its real, practical action in meeting the challenge of poverty alleviation.

Hence, considering WB goals of alleviating poverty and fostering development, the present work seeks to answer the following fundamental question: Can any trend be outlined in disbursements distribution in LAC? This umbrella-question is specified as follows.

(i) Knowing that the WB allegedly aims at combating poverty, can any trend be outlined in disbursements distribution in LAC in relation to these countries' social and economic profiling?

(ii) Bearing in mind that the disbursements distribution among economic sectors is a possible proxy for understanding the WB's view on development and poverty alleviation, can any trend be outlined in disbursements distribution in relation to economic sectors (such as agriculture, public administration, etc)?

The paper is divided into 5 sections, besides this introduction. While section 2 outlines the analytical contributions of the various approaches to $\mathrm{WB}$ and development assistance, the methodology for the analysis of resources distribution among countries is presented in section 3.We use the panel data estimation method with fixed effects, with information about 30 countries in LAC, and disbursements received by them from the WB during a 26-year period between 1985 and 2010. The database has been organized based on official data provided by the World Bank's Latin America division. Section 4 presents results and a discussion on the results of estimations made in section 3 . In section 5 , we look at sectorial disbursement distribution, with the double objective of $(i)$ identifying WB's disbursement priorities and, by doing so, identifying the priorities that have actually guided its assistance in the region and (ii) verifying if these priorities have been sustained throughout the period. Finally, section 6 brings conclusions and final remarks. 


\section{References for analysis}

For a start, we may establish that the World Bank (WB), hereby understood as the coupled institutions International Development Association (IDA) and International Bank for Reconstruction and Development (IBRD), is an International Financial Institution (IFI), classified as a Multilateral Development Bank (MDB), which issues loans and grants for the purpose of poverty reduction in countries around the globe, hereby understood as development assistance (DA), in a broad sense.

Development assistance should not be mistaken for Official Development Assistance (ODA), which comprises flows of official financing administered with the promotion of the economic development and welfare of developing countries as the main objective and stems from agencies or governmental departments that provide financial aid to non-governmental organizations (NGOs) and community-based organizations.

If one was to look only to ODA, in the present analysis, only IDA should be studied, decoupled from IBRD. As it is outlined in the institution's official webpage the IBRD's primary business is offering loans and policy advice to client governments, differing from IDA, whose main goal is to provide development assistance (in this case ODA) on terms which are more flexible and bear less heavily on the balance of payments than those of conventional loans, including those of the IBRD itself. For that reason, to analyze both IDA and IBRD altogether, the term development assistance suits the present study better, comprising the action and the assistance flows of both institutions.

As Hanmer, Pyatt and White (2002) put it, the problem of poverty is central to the $\mathrm{WB}$, and so is the planning of actions to face it and, allegedly, solve it. WB's antipoverty activities are focused on open markets, political participation and infrastructure as landmarks. In WB's initial operating decades, GDP was the basic criteria for assessing recipient countries' economic development and their policy efficacy and hence conditioning the bank's resources allocation. Under Robert McNamara (1968-1981) "the development understanding scope was broadened", to consider "involving a shift in societies life standards as a whole" (Rached, 2010, p.48). The importance of the social agenda grew in the next decades in WB disbursements planning, but economic growth remained important in the WB agenda - enriched with a number of political and institutional 
conditions that, in the Bank's view, would favour development (Rached, 2010, 49).

The 1990s and 2000s saw an increase in poverty in a number of countries due to economic liberalization policies, which were supported by the WB. One of its responses to those crises was a growing emphasis on "structural adjustment" programs, based on the argument that infrastructure financing could be made by the private sector, once legal and operational conditions were laid out by governments. Rached (2010, p.52) understands that the WB progressively incorporated in its assistance programs the perception that economic growth and poverty reduction require not only suitable economic policies, but also the strengthening of adequate institutions that would generate a "favourable environment" for development. There are indications which show that, in this period, WB moved from growth stimulus policies to poverty fighting focal policies (Ugá, 2004), which offers an important perspective on what will be shown in the coming sections as the operation of resources distribution so as to prioritize the generation of this favourable environment, mainly through the enhancement of public administration structures.

Ugá's perception seems to be in line with World Bank Group's goals, summarized in the title "End Extreme Poverty and Promote Shared Prosperity" (World Bank, 2013). As the document states, tackling extreme poverty depends on the increase of the poorest populations' welfare, which, in its turn, is conditioned to governance reforms that allow for the enhancement of public administration services delivery and, thus, improve overall economic and social environment (2013, p.15). Interestingly, this argument puts the State at the centre of development fostering through disbursements process - as is the case with WB and its resources distribution in Latin America. The Bank recognizes that while, on the one hand, State is not the only driver of development, it does play, on the other hand, "an important catalytic role" in speeding up the process of institutional and social change directed at rendering social inclusiveness and economic stability. That is the case of fiscal responsibility, which might be underestimated during the operation of wide range distributional policies that may produce short-lived gains but leave countries mired in debt, which, in its turn threatens the prosperity of coming generations. This is an example of the need for reforms of the State, so as to ensure transparency, accountability and the incentives that may impact and foster long term social and economic development. 
In practical terms, the creation, in 1992, of the Institutional Development Fund (IDF) is an indication of World Bank Group's awareness on the necessity of special efforts towards State structures. The Fund has since been focusing its action on 5 areas: governance and anticorruption, engagement with civil society organizations, use of country systems, program-for-results financing, and knowledge platforms.

Ten years after the launch of IDF, WB's 2002 World Development Report, entitled "Building institutions for markets", established that income from participation in the market is a condition for poverty reduction and once market efficiency is dependent on institutions-provided incentives, institutions should be designed, enhanced and innovated, so as to guarantee distribution, access, empowerment and competition amongst economic and social players (2002, p.3-8).

Currently, WB's main objective, as outlined in its official webpage, is to fight poverty, based on two goals the world should achieve by 2030: (i) end extreme poverty by decreasing the percentage of people living on less than US $\$ 1.25$ a day to no more than $3 \%$ and (ii) promote shared prosperity by fostering the income growth of the bottom $40 \%$ for every country.

Clearly, a natural and logical step taken by the analyst of these actions is to try and understand how effective the Bank's actions in facing poverty have been. That is the effort undertaken by authors such as, among others, Santiso (2001), who establishes the connection between political performance and inclusion as fundamental to economic feasibility of development assistance; Bourguignon and Sundberg (2008), who analyse the complexity of the causality chain between development assistance and development outcomes, and Ismi (2004), who, while analysing WB resources conditionality, claims that the Bank's work in Africa has been highly counter-productive and negative to the region.

The WB, then, should play an important role as an essential source of financial resources and technical assistance for developing countries. That means that it is not a bank in the ordinary sense, but a partnership to reduce poverty and support development, as it provides low-interest loans, interest-free credits, and grants to developing countries. These support a wide array of investments in such areas as education, health, public administration, infrastructure, financial and private sector development, agriculture, and environmental and natural resource management. Some of its projects are co-financed with governments, other 
multilateral institutions, commercial banks, export credit agencies, and private sector investors.

In Sogge's (2002) prologue, José Antonio Alonso offers a glance at the theoretical approach that includes DA in a context of global governance in terms of what is defined as governance by Keohane and Nye (2000). That is why it takes into consideration the globalized reality of the world and the perception that poverty - seen as an impeditive to development - is not simply an issue born within the boundaries of the countries haunted by it. This perception poses the question of both poverty and development as global issues that should, therefore, be considered, discussed and decided upon in organizations with global scope and, supposedly, inclusive institutional arrangements.

Sogge (2002, p. 10) himself presents an essential question on the matter of governance, considering if it "is reasonable that countries which normally benefit from an asymmetric international relations system are also those to whom the responsibility is given to correct (through foreign DA) the malefactions consequent of this very system".

This quotation marks the fundamentals of what he has decided to call governance literature on the $\mathrm{WB}$, as previously analysed by authors such as Swedberg (1986), Lichtensztejn and Baer (1987), Griffith-Jones (2002), Wade (1998), Allegret and Dulbecco (2003), Borges (2003), and Kapur (2006).All these authors, in one way or another, are worried about how countries are institutionally represented, how their voices are made heard within the organization and how open and permeable are to the countries' interests.

As previously stated, poverty demands the formulation of actions: the WB activities, projects distribution and development assistance depend on the definition and decision, which are, clearly, influenced by the concepts and ideas that the technical instances of the Bank consider important. As Hibou (2000) states, the WB does base its projects and actions on a canon, one economic theory, which leads us to agree with the author's claim that there can be no scientific approach to reality without values entailed in analyses themselves, so that the edifice of the Bank's discourse is rendered on at least four procedures: the choice of certain models, the omission of a number of rules in selected models, the introduction of some hypotheses to obtain a single solution, and the repudiation, be it explicit or not, of certain theories (Hibou, 2000). 
As she states, the Bank's conceptual framework for action is underpinned by liberal economic policy, which is made clear by a series of WB documents and analyses focused on the supposed positive effects of liberalization, presented by the author ${ }^{1}$.

Likewise, while analysing the World Development Reports, Teixeira (2009) asserts that market is prioritized over society, markedly in recommendations for Brazilian policy-makers to undertake greater market liberalization and seek rapid growth instead of looking for income distribution policies. The author stresses that the Bank's discourse, indicator of its own conceptions of poverty alleviation, growth and development, reduces social protection to a simple focus on those who are in extreme need, in lieu of truly transforming social and economic conditions in favour of profound social changes.

Pereira (2010), in his turn, presents the transformations of the WB's discourse in dealing, in the late 1990s, against all odds and its own previous postures, with the role of state as an important player in development. Besides, the author demonstrates the criticism of the Bank's scientific bases and biases while analysing poverty alleviation and development around the world: its research agenda is largely determined by political prescriptions lined up with the neoliberal schema.

While Hibou (2000) and Teixeira (2009) question the conceptions that inform the Bank's actions, Fuller (2002, p.3) serves as an interesting contribution, and a typical example of what we decide to call conceptions literature. In her work, the author points out "well based analytical perspectives on foreign aid", which may be transposed into WB's projects analysis, as previously proposed. According to her, one might see DA (and the Bank's projects distribution in LAC) through (i) an idealist perspective or (ii) a realist perspective.

From an idealist perspective, one might suppose that the WB's loans and credit flows would have been directed to LAC with a humanitarian concern, which means it would be reasonable to find larger projects amounts in those countries with a lower average income, in lieu of middle income countries. Therefore, one may conclude that, if WB's credits and loans projects flows were directed, in the period, to countries with a lower per capita income, then, the institution has, indeed, a humanitarian posture, 
aiming at countries where poverty is a problem, in line with its website's heading: "working for a world free of poverty".

From a realist perspective, DA flows should be seen as part of strategic concerns from the main players involved in the decision-making process within the WB markedly those likened to security and self-preservation. This perspective is clearly tributary to the Cold War moment, confluent to Alonso's tradition. In this context, according to Schraeder et al. (1998, p. 296 apud Fuller, 2002, p.3-4), DA "is perceived as only minimally related to recipient economic development and the humanitarian needs are downplayed". This perspective sets in the focus of the discussion the role of governance within the institution, as already pointed out by authors such as Swedberg (1986), Lichtensztejn and Baer (1987), Allegret and Dulbecco (2003) and Pereira (2010).

Fuller's analytical landmarks recognize the role of a conceptual framework or posture coupled with an institution's real action (Fuller, 2002). That is, precisely, what the authors of the present work seek: in analysing the amounts distributed to LAC countries and combining them with socio-economic indicators, we seek to test the Bank's proposition of a "poverty alleviation" agenda. Hence, we seek to analyse (i) the socio-economic profiling of WB disbursements in recipient countries and (ii) the distribution of resources according to economic sectors.

\section{Methodology for an analysis on resources distribu- tion among countries}

We move to econometric tests in order to assess if the WB has indeed distributed its resources in Latin America and the Caribbean, in the period between 1985 and 2010, in terms of countries poverty challenges: one should expect that a larger average amount of finance is directed to relatively less developed countries. Thus, a panel estimation method is applied considering fixed effects (Within estimator ${ }^{2}$ ), with information about 30

2 The Within estimator is commonly seen by a number of authors as a consistent tool for controlling the effects of analysis units' (in this case, countries) characteristics that do not vary in time (fixed effects). Dependent and independent variables, of each $i$ country and in each $t$ year are transformed into deviations in relation to the respective averages. For a deeper discussion on Within estimator and, specifically, on how deviations in relation to averages control fixed effects, see: Greene (1997), Baltagi (2001), Wooldridge (2002), Angrist and Pis- 
countries in Latin America and the Caribbean, between the years 1985 and 2010 (26 years), defined in function of the availability of data necessary to the tests ${ }^{3}$. The estimated models are based on the equations (1) and (2) below:

$$
\begin{aligned}
& d_{-} W_{i t}=\beta_{0}+\beta_{1} G D P \text { percapita }_{i t}+\beta_{2} \text { Poverty }_{i t}+\beta_{3} \text { Gini }_{i t}+ \\
& +\beta_{4} \text { Population }_{i t}+\beta_{5} I_{i t}+\beta_{6} X_{i t}+u_{i}+\varepsilon_{i t} \\
& d_{-} W B_{i t}=\alpha_{0}+\alpha_{1} G D P_{i t}+\alpha_{2} \text { Poverty }_{i t}+\alpha_{3} \text { Gini }_{i t}+\alpha_{4} \text { Population }_{i t}+ \\
& +\alpha_{5} I_{i t}+\alpha_{6} X_{i t}+u_{i}+\varepsilon_{i t}
\end{aligned}
$$

where: $\beta_{0}$ and $\alpha_{0}$ are constant (intercepts);

$d_{-} W B_{i t}$ is the dependent variable, that corresponds to the total disbursed amount by the WB (for the various sectors for which the bank offers financial assistance) received by country $i$ (in millions of US\$ at 2011 international prices) in year $t(t=1985,1986, \ldots, 2010)^{4}$; GDP per capita $_{i t}$ is country $i$ 's Gross Domestic Product (GDP) per capita in year $t$; GDP $P_{i t}$ is country $i$ 's GDP in year $t ; \beta_{1}$ and $\alpha_{1}$ are the coefficients associated, respectively, to these;

Poverty $_{i t}$ is the poverty rates in country $i$ in year $t$ (percentage of the population living on less than US\$3.10 a day at 2011 international prices); $\beta_{2}$ and $\alpha_{2}$ are the coefficients associated to it;

Gini $_{i t}$ is the Gini index in country $i$ in year $t ; \beta_{3}$ and $\alpha_{3}$ are the coefficients associated to it;

Population $_{i t}$ is the population size (number of inhabitants) in country $i$ in year $t ; \beta_{4}$ and $\alpha_{4}$ are the coefficients associated to it; $I_{i t}$ is a vector of institutional variables in country $i$ in year $t ; \beta_{5}$ and $\alpha_{5}$ are the vector of coefficients associated with these;

$X_{i t}$ is a vector of two variables that represent the GDP composition (investment and government expenditure) in country $i$ in year $t$; $\beta_{6}$ and $\alpha_{3}$ are the vector of coefficients associated with these; $u_{i}$ are the non-observed characteristics which differ among countries but which are fixed in time (fixed effects);

$\varepsilon_{i t}$ is the random error.

chke (2009) and Cameron and Trivedi (2009).

3 Estimations with heteroscedasticity-consistent standard errors.

4 Information made available by the WB: www.worldbank.org/en/region/lac/projects. 
GDP per capita and GDP variables have been obtained with Penn World Table 7.1 (PWT 7.1) $)^{5}$. Once the present study assesses if resources transferred by WB are influenced by levels of income in countries, these are two of the variables of higher interest, not employed in the same estimations for being collinear and, when coupled with Population, for resulting in perfect collinearity. Besides this technical explanation, the use of both variables instead of one is justified because they may each capture different analytical aspects. While per capita GDP may indicate WB's preference for countries with higher or lower levels of poverty (or average income), total GDP may indicate the bank's preference for smaller or larger economies. Larger economies, for example, can have larger synergies for WB's disbursements, which would maximize their efficiency. We may suppose, still, that WB would consider the interests of large capital groups, supposedly more interested in WB projects that would increase general efficiency, which is more plausible in larger economies.

In a broader perspective, if the coefficients associated with these variables $\left(\beta_{1}\right.$ and $\left.\alpha_{1}\right)$ are negative and significant, there will be evidence that do not refute the hypothesis of "adherence" between WB's resources disbursement decision and countries' profiling, which is the same as saying that the Bank is fulfilling its goal of a supporter and partner in the fight against poverty. On the other hand, if $\beta_{1}>0$ and/or $\alpha_{1}>0$ (significant), the evidences will suggest that the criterion for resources distribution is not compatible with what is expected from a multilateral development bank. In this scenario, resources are not directed, in their majority, to countries in greater need (least developed countries). Hence, one may affirm that WB is not acting effectively towards the fulfilment of the objectives one may expect from it to uphold. In this case, one may infer that the returns on projects in countries with higher income levels are higher and the bank would be distributing resources motivated by economic feasibility and return prospects.

The third variable of interest in this study is Poverty, calculated with WB data. It is inserted in the estimations with the objective of assessing if WB considers the portion of people living below the poverty line in its recipient countries as a decisive factor in its disbursements distribution.

5 Heston, Summers and Aten (2012): purchasing power parity (PPP) converted GDP (Laspeyres) at 2005 constant prices. For further details: https://pwt.sas.upenn.edu/php_site/pwt_index.php. 
WB reports and studies, besides external analyses, show that, since the 1990s, the Bank has started to prioritize focal poverty combating policies other than stimulating growth in poorer countries (Ugá, 2004; World Bank, 1988, 1989, 1993, 1994, 2000, 2001, 2002, 2013). Hence, estimated Poverty coefficients $\beta_{2}$ and $\alpha_{2}$, if positive (and significant), may also suggest that there is adherence in distribution criteria for LAC countries, which means that the Bank disburses larger amounts for countries with larger proportions of poor people.

Another interest variable is Gini, which is inserted in the estimations with the objective of capturing additional evidences related to the existence or non-existence of social motivation for fighting poverty in WB's disbursements decision ${ }^{6}$. It is important to underline that a development institution should prioritize least developed countries and countries with lower development levels that tend to have higher income concentration ${ }^{7}$. If there is a social preoccupation in disbursements, Gini variable coefficients $\left(\beta_{3}\right.$ and $\alpha_{3}$ ) must be positive (and significant); other results would refute this hypothesis.

The last interest variable is Population, used to control for the possibility of $\mathrm{WB}$, while deciding upon the disbursements distribution, considering countries' population sizes. On the one hand, the larger the number of inhabitants, the more elevated will be the number of people who may benefit from the investment, which could motivate the WB in case it is worried about socio-economic impacts of its disbursements. On the other hand, even if such preoccupation exists, the larger the number of inhabitants, the more elevated would be the probability of project success, once countries with larger populations would tend to have, in most sectors, larger capacity of generating revenue and small costs (scale economies), affecting projects' economic feasibility and return.

Hence, if estimated coefficients associated with the Population variable ( $\beta_{4}$ and $\alpha_{4}$ ) are positive (and significant), it is possible that it is due to a social bias that should motivate a multilateral development institution,

6 Gini index ranges from 0 to 1 , being 0 a perfect situation of income equality and 1 a scenario of complete concentration. Within this interval, the higher the index, more concentrated is income distribution (inequality). Data have been obtained in World Institute for Development Economic Research (http://www.wider.unu.edu/). For some countries, there are no data for all years in the analyzed period. In these cases, geometrical interpolations have been made.

7 A number of studies discuss the relation between economic development and income concentration, such as: Kuznets (1955), Deutsch and Silber (2000) and World Bank (2013). 
such as the WB; however, it is also possible that it is due to economic bias, in supporting economically feasible projects. Facing this possibility, the population must be controlled for, but its results analysis should also combine and be matched with GDP and Gini index.

According to Abrucio and Loureiro (2004), international organizations, such as the WB, have been advocating and broadcasting the idea that development, in many countries, shall not be achieved only with resources transfers for investments. Moreover, institutional reforms would be necessary in order to reduce inefficiencies in governments' resources allocation, so that practices such as corruption and cronyism are eliminated (or, at least, diminished), once they have a negative impact on economic performance. According to Schneider and Doner (2000), this (a larger focus on institutional change) is due to the influence of institutional theories in these organizations. The authors highlight, in this context, the World Bank, which stands up for democratic institutions as one of the pillars of developed countries, emphasizing their role in contracts guarantees, in legal processes efficiency and in decision transparency. Ugá (2004) and Rached (2010) state that, besides focal poverty combating policies, one of WB's priorities from the 1990s on, especially after the Washington Consensus, has precisely been those policies which induced countries into institutional reform processes.

Thus, it is possible that the WB decides upon the distribution of its disbursements according to countries' institutional framework. On the one hand, it could give privilege to countries that already have a "favourable" framework, closer to what the bank stands up for. On the other hand, it could privilege countries with a "non-favourable" institutional framework, aiming to induce them to implement institutional reforms. In order to control for these possible motivations, three political regime variables shall be considered in the estimations: democracy, autocracy and duration. Also, interactions among the three variables shall be incorporated. They are represented in equations (1) and (2) by vector $I_{i t}$, associated with coefficients $\beta_{5}$ and $\alpha_{5}$.

The institutional variables have been designed from information available in Polity IV database, from the Center for Systemic Peace. Considering a series of political-institutional characteristics, in this database, political regimes are classified - in line with Marshall and Cole's (2011) suggestion - with an index that ranges from -10 to 10 , being those countries with numbers between 6 and 10 considered democracies; -10 to - 6 , autocracy; -5 
to 5, an anocracy. According to the authors: democracy and autocracy are normally seen as contrasting and different forms of governance. The main differences are found in the ways executive power is acquired and transferred, how the political power is exercised and constrained, how the social order is defined and maintained, and how much influence public interests and opinion have on decision-making process. Therefore, anocracies can be understood as countries whose governments are not fully democratic, not fully autocratic but, instead, combine a, commonly, incoherent mix of democratic and autocratic traits and practices (Marshall; Cole, 2011).

Democracies have institutionalized procedures for open, competitive, and deliberative political participation; choose and replace chief executives in open, competitive elections; and impose substantial checks and balances on the discretionary powers of the chief executive. In autocracies, by contrast, citizens' participation is sharply restricted or suppressed; chief executives are selected according to clearly defined (usually hereditary) rules of succession from within the established political elite; and, once in office, chief executives exercise power with no meaningful checks from legislative, judicial, or civil society institutions.

According to this classification, democracy variable is a dummy that has 1 as value if the country $i$ in year $t$ has a score $i$ in the Polity $I V$ database between 6 and 10, or 0 as value if otherwise. The autocracy variable is also a dummy that has a value of 1 , if the country $i$ in year $t$ has a score between -10 and -6 , or 0 , if otherwise. Thus, the default will occur with countries classified as anocracies. A positive (and significant) coefficient associated with the democracy dummy would signal that the WB privileges countries with a "favourable" institutional framework. A positive (and significant) coefficient associated with autocracy dummy would indicate that WB privileges countries with a "non-favourable" institutional framework. Moreover, the duration variable (years during which the current regime is sustained) is also obtained from Polity $I V$ database: we consider its interactions with other political regime dummies to control for the current regime consolidation and changes prospects as motivations for disbursement decisions.

In the estimations, investment participation and government expenditure participation are also taken into account, represented in equations (1) and (2) by vector $X_{i t}$, associated to coefficients $\beta_{6}$ and $\alpha_{6}$. The first variable is the proportion of GDP that corresponds to investments and it is used to control for the fact that the WB disbursed amount to a country may be influenced 
by this country's ability to invest with its own resources, so the variable is a proxy for this capability. It is plausible to expect that the WB should disburse larger amounts for countries with lower capability of auto-investing.

The second variable is a proportion of GDP that corresponds to government expenditure. As outlined previously, international organizations have been involved with the idea that directing resources is not enough for development: inefficiencies in resources allocations by governments should also be reformed and reduced (Abrucio; Loureiro, 2004). The variable controls for the participation of government in the economy and, the larger it is, the more chances it has for influencing its efficiency.

It must be highlighted that the ideal would be for other controls to be incorporated in the estimations. However, there are no historical series for all countries in the years taken into account that may allow such conclusions. Facing this obstacle, the fixed effects consideration $\left(u_{i}\right)$ in the estimations induces the control of variables not observed as constant in time (or which vary little), but which are different among countries, thus guaranteeing larger robustness to the results. In order to test results robustness, taking into account the potential collinearity among explanatory variables, estimations will be made on models based on equations (1) and (2) with alternative specifications, with sub-groups of the explanatory variables considered.

Additionally, it is important to point out that the WB disbursements regression as a function of the explanatory variables in the same (current) year, that is, $d_{-} W B$ in $t$ as a function of per capita GDP, Population and Gini and other variables in $t$ may have an endogeneity problem: WB disbursements might be influenced by explanatory variables, but they may also be influenced by disbursements, which would compromise the causality attribution to the results. Besides, the bank's disbursements may be decided during the period of a year, while GDP (and other variables) are calculated after that same year's end. Hence, we can affirm that the WB does not decide on disbursements based on an assessment of variables in the current year, but in a retrospective manner, observing countries' 'lagged' characteristics, measured, for example, in the previous year. Stemming from this pre-assumption and aiming at dealing with the potential problem of endogeneity, additional estimations are made, represented by equations (3) and (4), in which disbursements in $\mathrm{t}\left(\mathrm{d}_{-} W B_{i t}\right)$ are regressed as a function of explanatory variables measured in the previous year:in $t-1$. For example, disbursements in 2010 would be determined by variables in 2009 . 


$$
\begin{aligned}
& d_{-} W B_{i t}=\beta_{0}+\beta_{1} G D P \text { percapita } i t-1+\beta_{2} \text { Poverty }_{i t-1}+\beta_{3} \text { Gini }_{i t-1}+ \\
& +\beta_{4} \text { Population }_{i t-1}+\beta_{5} I_{i t-1}+\beta_{6} X_{i t-1}+u_{i}+\varepsilon_{i t} \\
& d_{-} W B_{i t}=\alpha_{0}+\alpha_{1} G D P_{i t-1}+\alpha_{2} \text { Poverty }_{i t-1}+\alpha_{3} \text { Gini }_{i t-1}+ \\
& +\alpha_{4} \text { Population }_{i t-1}+\alpha_{5} I_{i t-1}+\alpha_{6} X_{i t-1}+u_{i}+\varepsilon_{i t}
\end{aligned}
$$

Non-observed and, thus, non-controlled factors in the estimations may influence decisions on resources distribution by the WB. For example, there is possibly a more intense preference, by the Bank, to transfer resources to certain countries, maybe because of historical processes or other reasons. If these preferences do not alter in time, fixed effects control for them. So, an interesting aspect has been observed during data collection: in the analyzed timespan, annual average disbursement per country was US\$ 356.28 million, but four of these countries had a highlight: Colombia (with twice the average); Argentina (with approximately 4.5 times the average); Brazil (more than 6 times the average); and Mexico (approximately 10.5 times the average).

Therefore, we have decided to run additional tests for equations (1) to (4), not considering these 4 countries, which, in general, are the ones with larger GDPs and per capita income indexes. The objective, then, is to verify if the obtained patterns for the full sample are influenced by these countries. Consequently, there is an evaluation on other motivations for these in relation to others. It is possible that adherence is or is not observed when one takes the complete sample into consideration, while the contrary may happen when we exclude the four main recipients. If that happens, one may infer that the WB prioritizes these four countries while for the others it bases its decisions on other criteria.

Finally, it is important to assess if WB motivations have changes throughout the selected timespan, due to institutional guideline changes - as mentioned, there are studies that suggest a change towards focal policies in the 1990s (Ugá, 2004; Rached, 2010). Therefore, we have chosen equations (5) and (6) below for these estimations. The analyzed timespan is divided in 5 (1985 to 1989, 1990 to 1994, 1995 to 1999, 2000 to 2004 and 2005 to 2010) and, for each of them we use a time dummy $\left(D T_{t}\right)$. These will be iterated to GDPpercapita and Poverty $\left(D T_{t}{ }^{*} G D P\right.$ percapita ${ }_{i t}$ and $D T_{t}$ ${ }^{*}$ Poverty $_{i t}$, respectively) variables. The default (comparison basis) will be the first period (1985 to 1989), so that results of iterations should be interpreted as variations of influence on disbursements made by the WB 
in comparison to the first period. These estimations are made for the full sample and for the reduced sample (without Colombia, Mexico, Brazil and Argentina).

$$
\begin{aligned}
& d_{-} W B_{i t}=\beta_{0}+\beta_{1} G D P_{\text {percapita }}+\beta_{2} \text { Poverty }_{i t}+\beta_{3} \text { Gini }_{i t}+ \\
& +\beta_{4} \text { Population }_{i t}+\beta_{5} I_{i t}+\beta_{6} X_{i t}+\beta_{7} D T_{t} * \text { GDPpercapita }_{i t} u_{i}+\varepsilon_{i t} \\
& d_{-} W B_{i t}=\beta_{0}+\beta_{1} \text { GDPpercapita } i t+\beta_{2} \text { Poverty }_{i t}+\beta_{3} \text { Gini }_{i t}+ \\
& +\beta_{4} \text { Population }_{i t}+\beta_{5} I_{i t}+\beta_{6} X_{i t}+\beta_{7} D T_{t}^{*} \text { Poverty }_{i t} u_{i}+\varepsilon_{i t}
\end{aligned}
$$

\section{Results}

Table 1 shows results obtained for the specifications that utilize interest variable per capita GDP instead of GDP and the others. One may infer that coefficients associated with per capita GDP in the current year are positive and significant at $10 \%$ in all specifications in which it is considered. In specification $\mathrm{V}$, which considers the variable in the previous year ('lagged') in order to deal with endogeneity and with the possibility of the WB deciding retroactively, the coefficient associated to the variable is also positive and significant at $10 \%$.

Hence, relatively robust evidences refute the hypothesis that adherence in WB's resources distribution to LAC countries' social condition, which allows us to conclude that the adopted criterion of disbursements distribution is incompatible with what is expected from a development bank that preaches the fight against poverty, with average disbursements being larger in countries with higher income levels. This means that resources are not preferentially directed to countries that are in graver need. Project economic feasibility can be the main motivation, rather than social aspects. This idea is reinforced by the lack of significance for coefficients associated with the remaining explanatory variables, which indicate the inexistence of motivations both regarding institutions and referring to GDP composition in the disbursements distribution. The non-significance of the Poverty and the Gini coefficients are other strong evidences that distribution does not have social traces for LAC countries. Moreover, the non-significance of the Poverty coefficients also refutes the hypothesis that the $\mathrm{WB}$ prioritizes countries with larger proportions of poor population by using focal policies. 
Table 1 Tests results: explanatory variable per capita GDP

\begin{tabular}{|c|c|c|c|c|c|c|c|}
\hline \multirow{2}{*}{$\begin{array}{l}\text { Variables/ } \\
\text { Specification }\end{array}$} & \multicolumn{6}{|c|}{ Current Year } & \multirow{2}{*}{$\frac{\text { Lagged }}{\mathrm{VII}}$} \\
\hline & I & II & III & IV & $\mathbf{v}$ & VI & \\
\hline \multirow{2}{*}{ GDP per capita } & (b) 0.178 & $0.150(b)$ & (b) 0.174 & & & & (b) 0.182 \\
\hline & $(0.071)$ & $(0.068)$ & $(0.088)$ & & & & $(0.087)$ \\
\hline \multirow{2}{*}{ Poverty } & -7.587 & -4.996 & & -15.749 & & & -15.775 \\
\hline & (18.99) & (16.28) & & $(11.50)$ & & & (19.51) \\
\hline \multirow{2}{*}{ Gini } & -9.241 & -14.500 & & & -1.509 & & -17.254 \\
\hline & (36.39) & (32.90) & & & $(34.89)$ & & (37.11) \\
\hline \multirow{2}{*}{ Population } & 3.422 & 3.448 & & & & 3.428 & 4.016 \\
\hline & (2.351) & $(2.20)$ & & & & $(2.281)$ & (2.571) \\
\hline \multirow{2}{*}{ Democracy } & 475.708 & & 478.076 & 272.397 & 482.768 & 515.571 & 473.805 \\
\hline & (583.99) & & (575.42) & $(386.30)$ & $(584.65)$ & (577.47) & (541.62) \\
\hline \multirow{2}{*}{ Autocracy } & 419.119 & & 551.195 & 577.476 & 859.569 & 832.879 & 235.650 \\
\hline & (2023.5) & & (1968.8) & $(1122.0)$ & (1994.9) & $(1968.0)$ & (2383.5) \\
\hline \multirow{2}{*}{ Duration } & -12.030 & & -6.000 & 0.093 & 12.083 & 8.925 & -9.475 \\
\hline & $(41.60)$ & & (41.23) & (32.50) & $(40.58)$ & (40.43) & (64.39) \\
\hline \multirow{2}{*}{$\begin{array}{l}\text { Democracy * } \\
\text { Duration }\end{array}$} & 9.236 & & 12.740 & 12.941 & 11.803 & 7.350 & 0.407 \\
\hline & (41.69) & & (41.38) & (33.01) & (41.71) & $(41.60)$ & (8.422) \\
\hline \multirow{2}{*}{$\begin{array}{l}\text { Autocracy * } \\
\text { Duration }\end{array}$} & 26.847 & & 15.411 & -13.233 & -16.896 & -14.817 & 4.010 \\
\hline & (150.13) & & (146.77) & $(61.80)$ & (147.89) & $(146.28)$ & (12.38) \\
\hline \multirow{2}{*}{$\begin{array}{l}\text { Investment } \\
\text { Participation }\end{array}$} & -20.666 & & -13.794 & -0.538 & 19.944 & 18.216 & -41.044 \\
\hline & $(38.88)$ & & (37.74) & (23.03) & (34.44) & (33.97) & (39.10) \\
\hline \multirow{2}{*}{$\begin{array}{l}\text { Government } \\
\text { Expenditure } \\
\text { Participation }\end{array}$} & 2.156 & & 2.902 & 11.954 & 16.413 & 14.984 & 2.242 \\
\hline & (47.26) & & $(46.52)$ & (33.35) & $(46.46)$ & $(46.18)$ & $(48.70)$ \\
\hline Constant & Yes & Yes & Yes & Yes & Yes & Yes & Yes \\
\hline $\mathrm{R}^{2}$ (overall) & 0.09 & 0.11 & 0.02 & 0.10 & 0.06 & 0.03 & 0.10 \\
\hline Prob $>F$ & 0.04 & 0.06 & 0.04 & 0.06 & 0.02 & 0.05 & 0.04 \\
\hline Observations & 362 & 382 & 364 & 519 & 363 & 364 & 349 \\
\hline Fixed Effects & Yes & Yes & Yes & Yes & Yes & Yes & Yes \\
\hline
\end{tabular}

Note: robust standard errors are in parentheses.

(a) Statistically different from zero at the .01 level.

(b) Statistically different from zero at the .05 level.

(c) Statistically different from zero at the 1 level. 
Table 2 Tests results: explanatory variable GDP

\begin{tabular}{|c|c|c|c|c|}
\hline \multirow{2}{*}{$\begin{array}{l}\text { Variables/ } \\
\text { Specifications }\end{array}$} & \multicolumn{3}{|c|}{ Current Year } & \multirow{2}{*}{$\begin{array}{r}\text { Lagged } \\
\mathrm{XI} \\
\end{array}$} \\
\hline & VIII & $\mathbf{I X}$ & $\mathbf{x}$ & \\
\hline \multirow{2}{*}{ GDP } & (a) 0.005 & (a) 0.005 & (a) 0.003 & (a) 0.004 \\
\hline & $(0.001)$ & $(0.002)$ & $(0.001)$ & $(0.001)$ \\
\hline \multirow{2}{*}{ Poverty } & -1.726 & -1.655 & & -11.404 \\
\hline & $(17.31)$ & $(15.00)$ & & $(19.00)$ \\
\hline \multirow{2}{*}{ Gini } & -5.300 & -7.968 & & -11.186 \\
\hline & (34.64) & (31.00) & & (35.30) \\
\hline \multirow{2}{*}{ Population } & $-7.160(b)$ & $-6.888(b)$ & & -3.823 \\
\hline & (3.401) & (3.182) & & (3.582) \\
\hline \multirow{2}{*}{ Democracy } & -69.157 & & 193.906 & 133.082 \\
\hline & $(590.02)$ & & (571.05) & (553.63) \\
\hline \multirow{2}{*}{ Autocracy } & -103.839 & & 211.515 & 6.639 \\
\hline & (1991.5) & & (1938.9) & (2364.4) \\
\hline \multirow{2}{*}{ Duration } & -18.086 & & -10.373 & -9.493 \\
\hline & $(40.40)$ & & (40.05) & (61.61) \\
\hline \multirow{2}{*}{ Democracy * Duration } & 19.803 & & 10.756 & 1.147 \\
\hline & $(41.02)$ & & $(40.73)$ & $(8.31)$ \\
\hline \multirow{2}{*}{ Autocracy * Duration } & 19.286 & & 8.826 & 0.126 \\
\hline & $(147.35)$ & & $(143.73)$ & (11.99) \\
\hline \multirow{2}{*}{$\begin{array}{l}\text { Investment } \\
\text { Participation }\end{array}$} & -17.941 & & -5.666 & -33.904 \\
\hline & $(36.45)$ & & $(33.97)$ & $(37.22)$ \\
\hline \multirow{2}{*}{$\begin{array}{l}\text { Government Expenditure } \\
\text { Participation }\end{array}$} & -9.162 & & -1.248 & -2.458 \\
\hline & $(46.12)$ & & $(45.54)$ & $(47.90)$ \\
\hline Constant & Yes & Yes & Yes & Yes \\
\hline $\mathrm{R}^{2}$ (overall) & 0.11 & 0.11 & 0.17 & 0.17 \\
\hline Prob $>F$ & 0.02 & 0.00 & 0.02 & 0.02 \\
\hline Observations & 362 & 382 & 364 & 349 \\
\hline Fixed Effects & Yes & Yes & Yes & Yes \\
\hline
\end{tabular}

Note: robust standard errors are in parentheses.

(a) Statistically different from zero at the .01 level.

(b) Statistically different from zero at the .05 level.

(c) Statistically different from zero at the 1 level.

Table 2, in its turn, shows results of estimations that employed GDP as alternative interest variable - rather than GDP per capita. It is noteworthy, yet again, that both variables have not been used in the same estimations 
because they are collinear, especially when coupled with Population. Furthermore, it is possible to test the adherence in relation to two aspects. GDP per capita would show a preference, by the WB, for countries with higher or lower poverty levels (or average income), which has been observed in the tests, as it is clear in comments on results from Table 1. Total GDP, in its turn, would capture a preference, by the WB, for larger economies, which has also been observed in the tests whose results are shown in Table 2. Coefficients of GDP variable are positive and significant at the $1 \%$ level in all specifications, including in XI, which considers the variable measured in the previous year ('lagged') to deal with probable endogeneity and retroactivity of WB decisions.

Results found for other variables in estimations in Table 2 also guarantee more evidences favourable to this argument. Coefficients associated with the Population variable are negative and significant at the $10 \%$ level, except for specification XI, in which it is considered lagged (keeping the negative sign) ${ }^{8}$. The negative coefficient associated with this variable may signal the absence of WB's preoccupation with potential socio-economic impacts of its disbursements, which tend to be more elevated in more populous countries. However, it may also indicate the absence of an 'economic' preoccupation of supporting projects that are economically feasible, considering that more populous countries tend to have, in a large part of its economic sectors, higher revenue generation capability and lower costs (economies of scale). The inexistence of social motivation in disbursement distribution for LAC countries can be reinforced by the non-significance of the coefficient associated with the Poverty and Gini variables in all specifications. Moreover, institutional variables and those related to GDP formation are also not significant, which suggests the absence of other motivations in financing disbursement distribution by the WB.

Table 3 shows results that do not take the Argentina, Brazil, Colombia and Mexico sample into account, once they are the larger recipients. In Poverty and Gini, estimated coefficients follow previous resulting patterns, signalling that social aspects may or may not be taken into account in WB decisions. On the other hand, per capita GDP and GDP have negatively influenced the amount transferred in the full sample, contrary to what has been observed in the reduced sample. Therefore, excluding the 4 largest 8 In previous estimations, coefficients associated with the Population variable may not have shown significance because of its probable collinearity to per capita GDP. 
Table 3 Tests results: sample without Argentina, Brazil, Colombia and Mexico

\begin{tabular}{|c|c|c|c|c|}
\hline \multirow{2}{*}{$\begin{array}{l}\text { Variables/ } \\
\text { Specifications }\end{array}$} & \multicolumn{2}{|c|}{ Current Year } & \multicolumn{2}{|r|}{ Lagged } \\
\hline & XII & XIII & XIV & XV \\
\hline \multirow{2}{*}{ GDP per capita } & (c) -0.025 & & (c) -0.031 & \\
\hline & $(0.013)$ & & $(0.020)$ & \\
\hline \multirow{2}{*}{ GDP } & & $-0.002(c)$ & & (b) -0.002 \\
\hline & & $(0.001)$ & & $(0.001)$ \\
\hline \multirow{2}{*}{ Poverty } & 2.454 & 1.903 & 0.182 & 0.204 \\
\hline & (3.216) & (3.089) & $(3.570)$ & $(3.464)$ \\
\hline \multirow{2}{*}{ Gini } & -4.756 & -5.753 & -9.600 & -10.550 \\
\hline & (5.915) & $(5.868)$ & (5.988) & $(10.90)$ \\
\hline \multirow{2}{*}{ Population } & -2.565 & 7.275 & 8.136 & 19.214 \\
\hline & $(10.60)$ & (12.27) & (11.05) & $(12.81)$ \\
\hline \multirow{2}{*}{ Democracy } & -22.671 & -19.341 & -77.102 & -90.561 \\
\hline & $(105.45)$ & $(103.95)$ & $(97.25)$ & $(97.21)$ \\
\hline \multirow{2}{*}{ Autocracy } & 25.118 & 45.754 & -204.102 & -233.951 \\
\hline & (302.32) & $(300.28)$ & $(346.23)$ & (345.36) \\
\hline \multirow{2}{*}{ Duration } & -7.793 & -7.490 & -18.638 & -17.260 \\
\hline & $(6.427)$ & (6.398) & (19.08) & (11.07) \\
\hline \multirow{2}{*}{ Democracy * Duration } & 1.905 & -0.348 & 1.483 & 1.093 \\
\hline & $(6.488)$ & $(6.586)$ & $(1.463)$ & $(1.476)$ \\
\hline \multirow{2}{*}{ Autocracy * Duration } & 0.299 & -0.011 & 0.458 & 0.373 \\
\hline & (22.02) & (21.93) & (1.947) & $(1.923)$ \\
\hline \multirow{2}{*}{$\begin{array}{l}\text { Investment } \\
\text { Participation }\end{array}$} & 3.714 & 4.455 & 0.547 & 1.353 \\
\hline & (6.217) & (6.197) & (6.179) & $(6.158)$ \\
\hline \multirow{2}{*}{$\begin{array}{l}\text { Government Expenditure } \\
\text { Participation }\end{array}$} & -4.748 & -4.740 & -5.914 & -6.283 \\
\hline & $(7.280)$ & $(7.250)$ & (7.379) & (7.336) \\
\hline Constant & Yes & Yes & Yes & Yes \\
\hline $\mathrm{R}^{2}$ (overall) & 0.03 & 0.08 & 0.12 & 0.14 \\
\hline Prob $>F$ & 0.06 & 0.04 & 0.02 & 0.02 \\
\hline Observations & 258 & 258 & 249 & 249 \\
\hline Fixed Effects & Yes & Yes & Yes & Yes \\
\hline
\end{tabular}

Note: robust standard errors are in parentheses.

(a) Statistically different from zero at the .01 level.

(b) Statistically different from zero at the .05 level.

(c) Statistically different from zero at the 1 level. 
recipients, the adherence hypothesis in relation to average or total income is verified as true. The results suggest a preference for the 4 big recipients, even though they present, in general, higher income levels, which influences the result for the full sample. However, for other LAC countries, the higher the total and per capita income, the larger the amount of WB resources disbursed.

Table 4 Tests results: interactions with period dummies

\begin{tabular}{|c|c|c|c|c|}
\hline \multirow{2}{*}{$\begin{array}{l}\text { Variables/ } \\
\text { Specifications }\end{array}$} & \multicolumn{2}{|c|}{ Full sample } & \multicolumn{2}{|c|}{ Reduced Sample* } \\
\hline & $\mathrm{XVI}$ & XVII & XVIII & XIX \\
\hline Dummy 1990-1994 * & 0.205 & & (a) 0.160 & \\
\hline GDP per capita & $(0.249)$ & & (0.043) & \\
\hline Dummy 1995-1999 * & 0.078 & & -0.001 & \\
\hline GDP per capita & $(0.290)$ & & $(0.052)$ & \\
\hline Dummy 2000-2004 * & -0.044 & & -0.003 & \\
\hline GDP per capita & $(0.310)$ & & $(0.058)$ & \\
\hline Dummy 2005-2010 * & 0.164 & & -0.003 & \\
\hline GDP per capita & $(0.357)$ & & $(0.067)$ & \\
\hline Dummy 1990-1994 * & & 2.752 & & (a) 5.931 \\
\hline Poverty & & (9.073) & & $(1.476)$ \\
\hline Dummy 1995-1999 * & & -3.753 & & (b) 3.863 \\
\hline Poverty & & (10.98) & & (1.827) \\
\hline Dummy 2000-2004 * & & -12.012 & & (b) 4.118 \\
\hline Poverty & & (11.05) & & $(1.840)$ \\
\hline Dummy 2005-2010 * & & -15.362 & & (a) 7.328 \\
\hline Poverty & & $(15.75)$ & & (2.499) \\
\hline Others Variables & Yes & Yes & Yes & Yes \\
\hline Constant & Yes & Yes & Yes & Yes \\
\hline $\mathbf{R}^{2}$ (overall) & 0.10 & 0.09 & 0.20 & 0.10 \\
\hline Prob $>F$ & 0.01 & 0.04 & 0.00 & 0.03 \\
\hline Observations & 362 & 362 & 258 & 258 \\
\hline Fixed Effects & Yes & Yes & Yes & Yes \\
\hline
\end{tabular}

Note: robust standard errors are in parentheses.

(a) Statistically different from zero at the .01 level.

(b) Statistically different from zero at the .05 level.

(c) Statistically different from zero at the 1 level.

* Without Argentina, Brazil, Colombia and México. 
Finally, Table 4 presents results for estimations with period variables iterated to GDPpercapita and Poverty $\left(D T_{t}{ }^{*}\right.$ GDPpercapita $_{i t}$ and $D T_{t}{ }^{*}$ Poverty $_{i t}$, respectively), having the 1985-1989 timespan as default (comparison basis). We only report results for these iterated variables. For the full sample, no change is observed in relation to per capita income and poverty numbers on WB disbursements. However, for the reduced sample (not taking Brazil, Colombia, Mexico and Argentina into account), per capita income has a significantly distinct influence in relation to the base period, in the 1990-1995 period (in the sense of higher non-adherence); for all others, there is no significant difference, but results are negative, which may signal that the bank has moved towards higher adherence in relation to other countries throughout time, which has been previously stated for the period average. The poverty index, in its turn, although not having been significant throughout the average period, has had its influence on WB decisions increased throughout time in comparison to the 1985-1989 period, which may suggest that the bank has started to consider this aspect more thoroughly (although not decisively) while transferring resources to LAC countries, except for the 4 big recipients. Therefore, we may suggest, in line with some studies, that WB has started to consider focal poverty combating policies for these countries.

\section{Disbursements distribution by major sectors}

Having defined the study's second goal as the understanding on areas in which the World Bank has concentrated its disbursements in Latin America and the Caribbean, the way the Bank classifies its loans and grants must be explained. Each of the WB's projects is classified according to a series of parameters, in a constantly updated table, available on its official

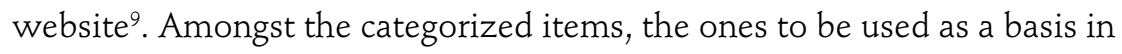
the present analysis are: Country; Approval Date; Project Total Cost (disbursement); Major-Sectors; Percentage of total amount directed to each Major Sector within the project.

Each of the WB's DA disbursements is classified in two macro dimensions ${ }^{10}$ : Major Themes and Major Sectors. This classification started in

$9 \mathrm{http}: / /$ web.worldbank.org/external/default/main?menuPK=258583\&pagePK=146740\&pi $\mathrm{PK}=512758$ \& theSite $\mathrm{PK}=258554$

10 http://siteresources.worldbank.org/PROJECTS/Resources/Sectors.pdf 
$2001^{11}$ and, before this date, all projects used to be sorted by 'Sectors' only. Hence, the projects have been retroactively re-assorted. This poses a methodological challenge, discussed by the WB itself on its webpage about projects classification: "when the [classification] list is revised, reclassification is never completely retrospective ${ }^{\prime 12}$. This means that the reclassification of projects may be mistaken or incomplete. We do believe, however, that the data loss is residual: only $5.06 \%$ of the analyzed period in the table available at the Bank's webpage are still classified in Sectors, which means our analytical material is $94.94 \%$ up-to-date with the new classification.

While Major Themes are wide vectors of classification that include, for instance, categories such as "Human Development" or "Rule of Law" in line with UN's Millennium Goals -, Major Sectors are more specific, clearly verifiable in the economic reality of a country. According to WB's classification, there are ten Major Sectors, identified by conventionalized acronyms as follows: Agriculture, fishing and forestry (AX); Public Administration, law and justice (BX); Information and Communications (CX); Education (EX); Finance (FX); Health and other social services (JX); Energy and Mining (LX); Transportation (TX); Water, sanitation and flood protection (WX); Industry and Trade (YX).

In order to have a clear understanding of what a Major sector is, let us briefly analyze the Sectors each Major Sector encompasses. This should shed light on the coming analysis. According to WB (2001), sectors are high-level sets of economic activities, whose definition is based on the types of goods or services produced; they have the UN classification of economic sectors as point of reference; they are mutually exclusive; they are commonly used to indicate which part of the economy is supported by the Bank intervention.

While the AX Major Sector encompasses sectors such as (i) agricultural extension and research, (ii) animal production, (iii) crops, (iv) forestry, (v) irrigation and drainage; the BX Major Sector encompasses ( $i$ ) central government administration, (ii) compulsory pension and unemployment insurance, (iii) law and justice, (iv) sub-national government administration. The CX Major Sector encompasses (i) information technology, (ii) media, (iii) postal services, (iv) telecommunications. The EX Major Sector encom-

11 http://web.worldbank.org/WBSITE/EXTERNAL/PROJECTS/0,,contentMDK:20061207 pagePK:41367 piPK:51533 theSitePK:40941,00.html

12 http://data.worldbank.org/about/country-classifications/country-and-lending-groups 
passes (i) adult literacy/non-formal education, (ii) pre-primary education, (iii) primary education, (iv) secondary education, (v) tertiary education, (vi) vocational training. The FX Major Sector encompasses (i) banking, (ii) capital markets, (iii) housing finance and real estate markets, (iv) non-compulsory pensions, insurance and contractual savings, (v) micro and SME-finance, $(v i)$ payment systems, securities clearance and settlement and (vii) general finance sector. The JX Major Sector encompasses ( $i$ ) health and (ii) other social services. The YX Major Sector encompasses (i) agricultural marketing and trade, (ii) agro-industry, (iii) housing construction, (iv) other domestic and international trade, (v) other industry and (vi) petrochemicals and fertilizers. The LX Major Sector encompasses (i) district heating and energy efficiency services, (ii) mining and other extractive, (iii) oil and gas, (iv) power and (v) renewable energy. The TX Major Sector encompasses (i) aviation, (ii) ports, waterways and shipping (iii) railways and (iv) roads and highways. The WX Major Sector encompasses (i) flood protection, (ii) sanitation, (iii) sewerage, (iv) solid waste management and (v) water supply.

In the WB's projects table, each project can be classified in up to 5 Major Sectors, connected, in their turn, to 1 Sector each (this means one project's disbursement amount may be divided into 1, 2, 3, 4 or 5 Major Sectors and, thus, 1, 2, 3, 4 or 5 Sectors). The same rationale is used in the classification with Major Themes. However, bearing in mind the more practical, sectoral character of Major Sectors, we have decided to abstain from analysing Major Themes. Besides, the Major Sectors are more commonly used by the current literature on the World Bank (see Pereira, 2010) than the Major Themes. Once we would be dealing with a total amount of 11 Major Themes, 66 Themes, 10 Major Sectors and 57 Sectors (if all classifying vectors were to be taken into consideration), we have decided to reduce this analytical spectrum to only 10 variables (besides countries, of course): only the ten aforementioned Major Sectors. Therefore, values relative to each Sector will be considered as the value disbursed for the Major Sector, our main analytical basis.

The complexity of projects classification is directly proportional to the organizational-methodological challenge present in a research whose objective is to frame and scrutinize the vast projects spectrum proposed by the WB. And it is precisely this extreme complexity that imposes the necessity of choice and the definition of a methodological approach that is 
simple without losing its substance, whereas complex, without being incomprehensive. Having this said, the data hereby used encompasses 1,791 WB projects, classified in 1, 2, 3, 4 or 5 Major Sectors each, throughout 26 years, in 31 countries.

The reclassification made by the WB in 2001 is also the fundamental reason for the period choice in the present study: regressively, it seems to substantially and safely span projects only until the mid-1980s. Before that time, most of the projects are still classified in Sectors only. This is why we have decided to look upon the period between the years of 1985 and 2010.

To make the analysis clear and more comprehensive, we have decided to split this period in 5 sub periods: 1985-1989, 1990-1994, 1995-1999, 2000-2004 and 2005-2010. Following Pereira's (2010) work on the subject, this cleavage choice is arbitrary and does not seem to follow any changes neither in the economic reality of the region nor in the WB's own institutional framework. However, it offers a clear glimpse, as follows, on the steep changes in projects' distribution without clear reasons: the quinquennial hinge offers, at least, some reference to locate happenings and changes in the political and economic international scenario. Moreover, in order to make data visualization clearer, we have adapted a classification adopted by some public finance works, namely the function expenses (Oxley; Martin, 1991; Saunders, 1993): social policies (merit goods); infrastructure (economic services); economic sectors and public administration and state (pure goods).

By analysing Table 5 first quinquennium (1985-1990), one may infer that projects in the region in the period were concentrated in the 'Agriculture, Fishing and Forestry' Major Sector, whose amount was $12 \%$ superior to the second and third on the list, as the table shows. It is interesting to notice how little importance was given in the period for 'Public Administration, Law and Justice', which will change radically in the subsequent periods.

Moving to the next quinquennium (1990-1994), the soaring positive variation (2471\%) in projects distribution in the 'Public Administration, Law and Justice' Major Sector is flagrant. Agriculture, which had 30\% of all projects in the previous period, had a negative variation of $41 \%$ in terms of amount disbursed, giving space for other growing Major Sectors, like 'Information and Communications' (391\%), 'Education' (303\%), 'Water and Sanitation' (117\%), 'Health and other social services' (115\%), 'Energy and Mining' (107\%) and 'Industry and Trade' (80\%). 
Interestingly, the total amount disbursed in this period had a positive variation of $92 \%$ (Table 5 ).

As Tables 5 and 6 show, once again, in the third quinquennium (19951999), there is a prevalence of 'Public Administration, Law and Justice' as a priority in WB's disbursements in the period between 1995 and 1999, still with a large share of total (29\%) and a positive variation in amount of money disbursed of $9 \%$. In second place, 'Finance' had a positive variation of $95 \%$. 'Health and other Social Services' Major Sector has a remarkable positive variation of $193 \%$.

Table 5 Total WB disbursements variation (\%) in relation to the previous quinquennium, in LAC, by Major Sector, between 1985 and 2010

\begin{tabular}{|c|c|c|c|c|c|}
\hline Major Sector & $\begin{array}{r}1985-1989 \\
\text { to } \\
1990-1994\end{array}$ & $\begin{array}{r}1990-1994 \\
\text { to } \\
1995-1999\end{array}$ & $\begin{array}{r}1995-1999 \\
\text { to } \\
2000-2004\end{array}$ & $\begin{array}{r}2000-2004 \\
\text { to } \\
2005-2010\end{array}$ & $\begin{array}{r}1985-1989 \\
\text { to } \\
2005-2010\end{array}$ \\
\hline $\begin{array}{l}\text { Social Policies } \\
\text { (merit goods) }\end{array}$ & 163.6 & 16.2 & -5.8 & 249.0 & 618.7 \\
\hline Education & 302.7 & -24.1 & 2.6 & 159.5 & 400.1 \\
\hline Water and Sanitation & 108.2 & -41.5 & -45.8 & 634.6 & 318.3 \\
\hline $\begin{array}{l}\text { Health and Other } \\
\text { Social Services }\end{array}$ & 115.2 & 193.2 & 3.5 & 225.7 & 1.373 .7 \\
\hline $\begin{array}{l}\text { Infrastructure } \\
\text { (economic services) }\end{array}$ & 80.9 & -25.5 & -47.2 & 416.7 & 196.4 \\
\hline Energy and Mining & 107.3 & -64.8 & -33.4 & 469.4 & 128.1 \\
\hline Transportation & 62.4 & 0.7 & -54.0 & 432.8 & 225.7 \\
\hline $\begin{array}{l}\text { Information and } \\
\text { Communication }\end{array}$ & 391.0 & -78.8 & 248.7 & 103.6 & 276.1 \\
\hline Economic Sectors & -15.1 & 4.1 & -33.1 & 197.2 & 16.6 \\
\hline $\begin{array}{l}\text { Agriculture. Fishing } \\
\text { and Forestry }\end{array}$ & -41.4 & -55.0 & -33.9 & 373.5 & -34.9 \\
\hline Industry and Trade & 80.1 & -41.3 & -9.9 & 291.3 & 177.1 \\
\hline Finance & -2.8 & 95.5 & -37.4 & 126.0 & 49.8 \\
\hline $\begin{array}{l}\text { Public Administration } \\
\text { and State (pure goods) }\end{array}$ & $2,471.2$ & 8.9 & -3.0 & 136.8 & $3,612.6$ \\
\hline $\begin{array}{l}\text { Public Administration, } \\
\text { Law and Justice }\end{array}$ & $2,471.2$ & 8.9 & -3.0 & 136,8 & $3,612.6$ \\
\hline Total & 91.4 & 1.0 & -19.3 & 219.4 & 242.3 \\
\hline
\end{tabular}

Source: Calculations made by the authors, based on WB's Projects Database for LAC. 
It is also interesting to notice how 'Education', 'Water and Sanitation' 'Agriculture, Fishing and Forestry', 'Industry and trade', 'Energy and Mining' and 'Information and Communication' have had expressive negative variations, $-24 \%,-44 \%,-55 \%,-41 \%,-65 \%,-79 \%$ in relation to the previous quinquennium. The total amount disbursed for the region, however, had little variation $(+0.6 \%)$.

'Public Administration, Law and Justice' still seems to be a key Major Sector for the WB in the period comprised between 2000 and 2004, despite a loss of $3 \%$ in the amount disbursed in comparison to the period 1995-1999. The Major Sector keeps a share of 35\% of total disbursements in the period, growing in numbers, we may infer, because of the loss of other Major Sectors.

The same happens to the 'Health and other Social Services' Major Sector, which, despite the negative variation of $54 \%$, reached second position, surpassing 'Finance', with a share of $20 \%$ of total disbursements. Despite having had a soaring positive variation of $249 \%$, 'Information and Communication' still maintain the last place in the list, with a $1 \%$ share of total, showing, alongside with 'Industry and Trade' and 'Finance' positive variations in relation to the previous quinquennium. All others have had negative variations that reach from $-3 \%$ to $-54 \%$, as well as the total disbursed amount for the region $(-20 \%)$.

Finally, the 2005-2010 quinquennium shows the prevalence of 'Public Administration, Law and Justice' as a priority of disbursements of WB in LAC. Despite the positive variation in the amount defined for this Major Sector $(+37 \%)$, in comparison to the previous period, its share of total has decreased from $35 \%$ to $22 \%$.

The positive variation of all other Major Sectors is remarkable, $+4 \%$ (Information and Communications), $+26 \%$ (Finance), $+59 \%$ (Education), $+126 \%$ (Health and Other Social Services), $+191 \%$ (Industry and Trade), $+274 \%$ (Agriculture, Fishing and Forestry), +333\% (Transport), +369\% (Energy and Mining), $+535 \%$ (Water and Sanitation). This encompasses, it seems, a full boost in $\mathrm{WB}$ projects in this period, with a total positive variation of $+119 \%$ in the region.

Table 6 summarizes total disbursed amounts and share in total disbursements for each of the Major Sectors. It is interesting to notice that the 'Public Administration, Law and Justice Major Sector' has been the main focus of disbursements in the region during the period, in terms of 


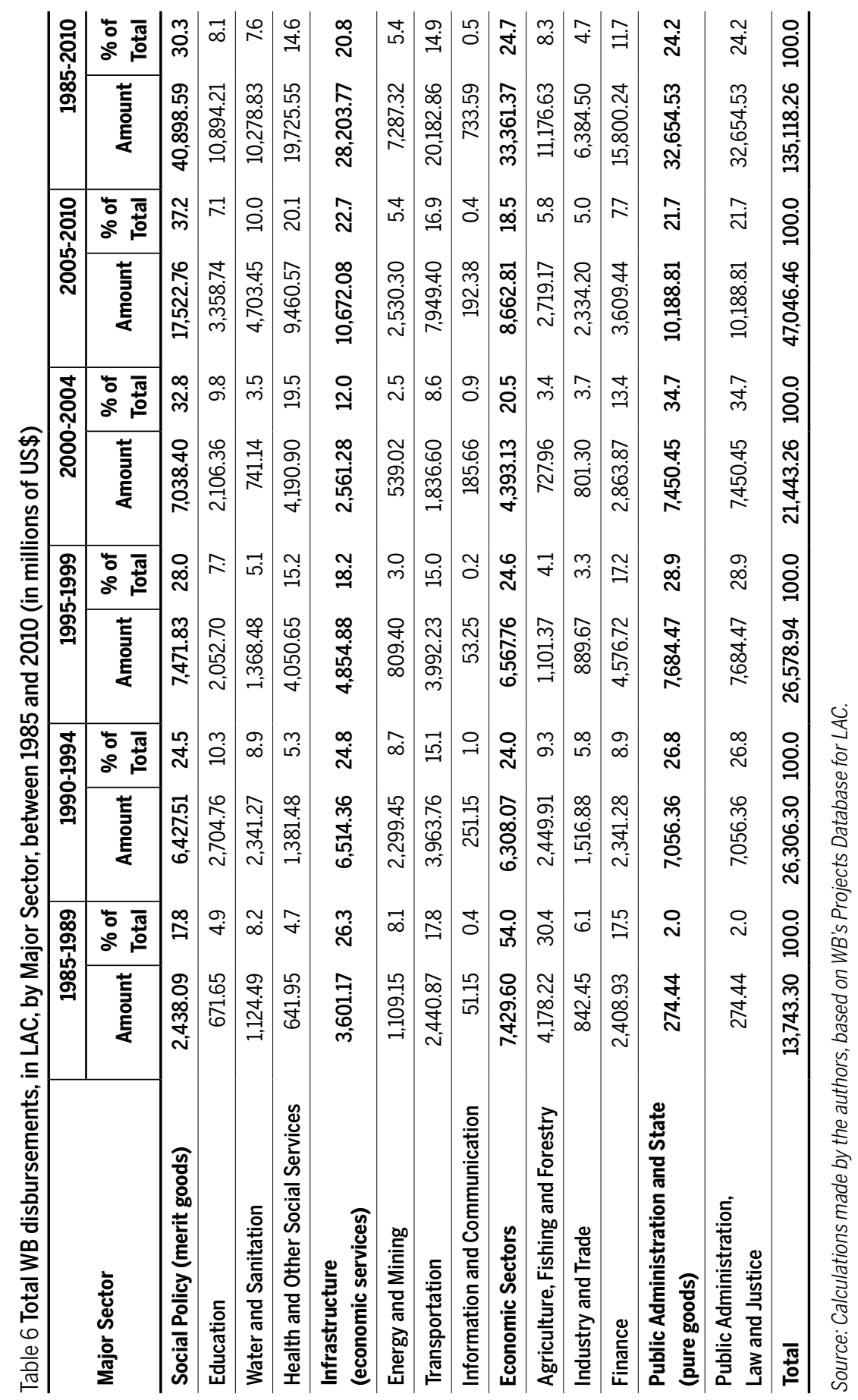


total amount (almost 33 billion dollars), total share (almost a quarter of all disbursements) and of total variation (the accumulated growth of investment in this Major Sector sums up to 25 times, while the second in growth - 'Information and Communication' - considering its almost irrelevant participation in total share, grew no more than 5.6 times). This is the clearest trend perceived from data analysis on disbursements sectorial distribution. Finally, in relation to the Public Administration, Law and Justice' Major Sector may point out to an aspect discussed in section 3: the fact that international organizations, such as the WB, should not focus its disbursements only on pure investment, but also on institutional reforms that can lower governments inefficiency (Schneider; Doner, 2000; Abrucio; Loureiro, 2004).

\section{Final remarks}

The analysis on WB disbursements distribution among Latin America and the Caribbean countries and among economic sectors (Major Sectors) between 1985 and 2010 has attested that (i) there is no adherence between financing distribution and socio-economic conditions of recipient countries and that (ii) sectoral distribution suggests that there is adherence under what the WB understands as fighting poverty: supporting financing initiatives in Public Administration, Justice and Law, which have concentrated an average of $25 \%$ of resources between 1985-2010, an almost identical percentage to that disbursed to pure social policies (merit goods).

This paper proposes the concept of adherence, which aimed at serving as an analytical landmark: adherence is, precisely, the approximation between countries' real needs and the Bank's real actions; its identification would mean that, in LAC, in the period analyzed, WB has truly played its role in alleviating poverty by looking for those in graver need. Adherence might have been confirmed if higher disbursements amounts had been offered to countries with relative lower economic and social standards.

Data show, however, that disbursements distribution is incompatible with what is expected from a development bank that preaches the fight against poverty: in the period analysed, average disbursements have been larger in countries with higher income levels. This means that resources are not preferentially directed to countries that are in graver need. Quite the op- 
posite, countries with higher income levels have been awarded relatively larger amounts of disbursement. Moreover, neither political regimes nor GDP composition seem to play a role as a distribution criterion.

The analysis made with both reduced and full sample offers an interesting trend, with resources distribution concentrated in the largest countries (Brazil, Mexico, Argentina and Colombia). The sample that excludes these four countries has shown higher non-adherence in terms of per capita income in the pivotal period of 1990-1995, whilst in other periods no adherence has been identified. That is to say that low income and poverty have not played a decisive role - though slightly more significant as time passed - in the resources distribution in the analysed period. The full sample has been biased by the size of the four largest countries: higher income has pulled higher disbursements.

One may wonder that project economic feasibility may be the main criterion, rather than social aspects. This idea is reinforced by the lack of significance for coefficients associated with the remaining explanatory variables, which indicate the inexistence of motivations regarding institutions and referring to GDP composition in the disbursements distribution. The non-significance of the Gini coefficient is another strong evidence that distribution does not have social traces.

It is possible to suppose that this same focus guides the resources concentration on 'Public Administration, Law and Justice', which have been prioritized over 'Education' and 'Health' - items that should aim at reducing poverty-related problems as a core goal. Sectoral distribution, therefore, may be a significant indication that WB sees fighting poverty as the management of institutional conditions that, once adequate, can enhance resources efficacy. There would be adherence, then, of resources distribution throughout the 20-year span (1990-2010), focusing on 'Public Administration, Law and Justice'. That conclusion is in line with the WB 2013 document on fighting extreme poverty and 2002 World Development Report, which stress the importance of reforming institutions in order to provide better access to market and, hence, more significant social and economic development. That would also be a possible explanation for the reasons why WB privileges resources channelling to countries with a higher institutional development - and not only poorer countries, which would supposedly have less developed capabilities of efficiently applying resources and promoting social development. 
Anyway, expressive oscillations such as those observed from quinquennium to quinquennium, as shown in Tables 5 and 6 , remain without explanation.

\section{References}

ABRUCIO, F. L.; LOUREIRO, M. R. Finanças públicas, democracia e accountability. In: BIDERMAN, C.; ARVATE, P. Economia do setor público no Brasil. Campus, Rio de Janeiro, 2004.

ANGRIST, J. D.; PISCHKE, J. S. Mostly harmless econometrics: an empiricist's companion. Princeton: Princeton University Press, 2009.

BALTAGI, B. H. Econometric Analysis of Panel Data. Wiley and Sons Ltda., 2001.

BHALLA, S. Governance in development: WB and IMF in the crossroads. 2006

BOURGUINGNON, F; SUNDBERG, M. Aid Effectiveness - Opening the Black Box. World Bank, 2005.

BUIRA, A. Reforming the governance of IMF and World Bank. Anthem Press, 2005.

FOCH, A. Governance of the World bank: analysis and implications of the decisional power of the G10. Centre d'économie de la Sorbonne. 2007

FULLER, S. A question of motivations: determining why donor countries give aid. Res PublicaJournal of Undergraduate Research, v.7, issue 1, Article 7, 2002.

GRIFFITH-JONES, S. Governance of the World Bank. London: DFID, 2002.

HANMER, L.; PYATT, G.; WHITE, H. What do the World Bank's Poverty Assessments teach us about poverty in Sub-Saharan Africa? Wiley, 2002.

HANSEN, H.; TARP, F. Aid Growth Regressions. Credit research paper. 2000.

HIBOU, B. The Political Economy of the World Bank's Discourse. 2000.

ISMI, A. Impoverishing a continent: World Bank and IMF in Africa. July, 2004

KALUZA, K.; KALUZA, Mari. Governance and accountability of the World Bank. University of Iowa, 2008.

KAPUR, D. The "Knowledge" Bank. In: BIRDSALL, Nancy. Rescuing the World Bank. Washington: Center for Global Development, 2006.

KEOHANE, R.; NYE, J. Power and interdependence. Boston, Little, Brown. 2000

LICHTENSZTEJN, S.; BAER, M. Fundo Monetario Internacional e Banco Mundial: estratégias e políticas do poder financeiro. São Paulo: Brasiliense, 1987.

MARSHALL, M. G.; COLE, B. R. Global report 2011: conflict, governance, and state fragility. Centre for Systemic Peace, 2011

NATH, S.; SOBHEE, S. Aid motivation and donor behavior. University of Mauritius, 2005.

OXLEY, H.; MARTIN, J. P. Controlling government spending and deficit: trends in the 1980 s and prospects for the 1990s. OECD Economic Studies, n. 17, p. 145-189, 1991. 
PEREIRA, J. M. M. O Banco Mundial como ator político, intelectual e financeiro. Rio de Janeiro: Civilização Brasileira. 2010.

RACHED, G. As alterações na política de desenvolvimento do Banco Mundial no contexto das transformações internacionais. Oikos, Rio de Janeiro, v. 9, n.1, p. 41-68, 2010.

SANTISO, C. Good governance and aid effectiveness. The Georgetown Public Policy Review, John Hopkins University, v.7, n.7, 2001.

SAUNDERS, P. Recent trends in the size and growth of government in OECD countries. In: GEMMELL, N. (Ed.). The Growth of the Public Sector, Edward Elgar Publishing, Aldershot, p.17-33, 1993.

SCHNEIDER, B. R.; DONER, R. The New Institutional Economics, business associations, and development. Brazilian Journal of Political Economy, v. 20, n. 3, jul/sep, 2000.

SCHRAEDER, P.; HOOK, S.; TABLES, B. Clarifying the foreign aid puzzle. John Hopkins University, 1998.

SWEDBERG, R. The Doctrine of Economic Neutrality of the IMF and the World Bank. Journal of Peace Research, v. 23, n. 4. 1986.

SOGGE, D. Dar y tomar - que ocurre com la ayuda internacional? Bcl: Icaria, 2002.

TEIXEIRA, R. V. Para uma crítica da concepção de política social do Banco Mundial na cena contemporânea. Tese de mestrado. Vitória, 2009.

UGÁ, V. D. A categoria "pobreza” nas formulações de política social do Banco Mundial. Revista de Sociologia Política, n.23, nov., 2004.

VIANNA JR., A. (Org). A Estratégia dos Bancos Multilaterais para o Brasil. Brasília: Rede Brasil, 2008.

VIKAS, N. World Bank: a step forward and a step backward. London School of Economics, 2001.

WADE, R. Showdown at the World Bank. New Left Review, n. 7, Jan/Feb 2007.

WORLD BANK. Report on Adjustment Lending. Washington, D. C.: World Bank, 1988.

WORLD BANK. Strengthening trade policy reform. Washington, D. C.: World Bank, 1989.

WORLD BANK. Democracy and the "Washington Consensus". Washington, D. C.: World Bank, 1993.

WORLD BANK. Adjustment in Africa. Washington, D. C.: World Bank, 1994.

WORLD BANK. World Development Report: Attacking Poverty. Washington, D. C.: World Bank, 2000.

WORLD BANK. World Bank Sectors / Final - 12 17 01. Washington, D. C.: World Bank, 2001.

WORLD BANK. World Development Report: Building Institutions for Markets. Washington, D. C.: World Bank, 2002.

WORLD BANK. End extreme poverty and promote shared prosperity. Washington, D. C.: World Bank, 2013.

\section{About the authors}

Renato Câmara Nunes Dias - rcndias@gmail.com

Instituto de Relações Internacionais - Universidade de São Paulo (USP), São Paulo, SP.

Carlos César Santejo Saiani - carlossantejo.saiani@gmail.com

Instituto de Economia da Universidade Federal de Uberlândia, Uberlândia, MG. 
CarlosEduardo Carvalho - cecarv@uol.com.br

Pontifícia Universidade de São Paulo (PUC-SP), São Paulo, SP.

Ana LúciaPinto da Silva - lucinhaps@uol.com.br

Universidade Presbiteriana Mackenzie, São Paulo, SP.

\section{About the article}

Submission received on March 29, 2015. Approved for publication on February 16, 2016. 